\title{
PENGARUH LATIHAN INTERVAL RUNNING DENGAN CONTINUOUS RUNNING TERHADAP KADAR HEMOGLOBIN DAN VO2 MAX PADA ATLET BASEBALL BINAAN USBC UNIVERSITAS NEGERI MEDAN 2018
}

\author{
Oleh \\ Rosmaini Hasibuan $^{1}$, Rendy Zaenury Damanik ${ }^{1}$ \\ ${ }^{1}$ Fakutas Imu Keolahragaan, Universitas Negeri Medan \\ Email : $\underline{\text { rendyzd22@gmail.com }}$
}

\begin{abstract}
Abstrak
Tujuan dari penelitian ini adalah untuk mengetahui pengaruh latihan Interval Running dengan Continuous Running terhadap kadar Hemoglobin dan VO2 Max pada atlet baseball binaan USBC Universitas Negeri Medan tahun 2018. Metode penelitian adalah metode eksperimen. Desain penelitian Pretes - Postest Group Design. Latihan dilakukan selama 6 minggu dengan program latihan. Teknik analisis data pada penelitian ini menggunakan uji-t. Hasil penelitian menunjukkan penurunan rerata kadar Hemoglobin setelah menjalankan program latihan Interval Running sebesar 14,73 g/dL yang sebelumnya sebesar $14,85 \mathrm{~g} / \mathrm{dL}$ dan setelah menjalankan program latihan Continuous Running 15,00 g/dL yang sebelumnya $15,47 \mathrm{~g} / \mathrm{dL}$. Hasil uji analisis diperoleh nilai $\mathrm{p}=0,526$, yang menunjukkan ada penurunan namun tidak/terdapat perbedaan yang bermakna p>0,05. Hasil penelitian menunjukkan terjadi peningkatan rerata VO2 Max setelah menjalankan program latihan Interval Running sebesar $40,21 \mathrm{ml} / \mathrm{kg} / \mathrm{menit}$ yang sebelumnya $38,03 \mathrm{ml} / \mathrm{kg} / \mathrm{menit}$ dan setelah menjalankan program latihan Continuous Running sebesar $42,86 \mathrm{ml} / \mathrm{kg} / \mathrm{menit}$ yang sebelumnya $38,07 \mathrm{ml} / \mathrm{kg} / \mathrm{menit}$. Hasil uji analisis diperoleh nilai $p=0,140$, menunjukkan ada peningkatan namun tidak terdapat perbedaan yang bermakna $p>0,05$. Kesimpulan tidak terdapat perbedaan yang bermakna antara latihan Interval Running dengan Continuous Running terhadap kadar Hemoglobin dan VO2 max pada atlet baseball binaan USBC Universitas Negeri Medan tahun 2018.
\end{abstract}

Kata Kunci: Interval Running, Continuous Running, Hemoglobin dan VO2 Max

\section{A. PENDAHULUAN}

Cabang olahraga baseball saat ini sudah melebar luas di Indonesia dan mengalami perkembangan yang sangat baik. Kemajuan tersebut dapat dilihat dari banyaknya kalangan mahasiswa/i dan pelajar yang menggeluti cabang olahraga baseball. Dalam permainan baseball, daya tahan merupakan faktor yang sangat penting karena menggunakan waktu yang lama.

Tingkat VO2 Max dan Haemoglobin pemain baseball harus tinggi karena VO2 Max merupakan indikator tingkat daya tahan seorang pemain dalam pertandingan baseball. Daya tahan adalah keadaan atau kondisi tubuh yang mampu untuk bekerja untuk waktu yang lama, tanpa mengalami kelelahan yang berlebihan setelah menyelesaikan pekerjaan tersebut (Harsono 1988:155). Menurut Hairy (1989:186) 
VO2 max adalah nilai konsumsi oksigen maksimal. Artinya VO2 menunjukkan volume oksigen yang dikonsumsi, biasanya dinyatakan dalam liter atau mililiter. VO2 max ini adalah suatu tingkatan yang kemampuan tubuh yang dinyatakan dalam mililiter/kg/menit (Ismanda, dkk, 2017:334). Selain VO2 Max terdapat komponen dalam tubuh yang tidak dapat dipisahkan karena hal ini berkaitan dengan kemapuan dari VO2 Max pada tubuh manusia yaitu kadar Hemoglobin $(\mathrm{Hb})$ pada seseorang. Menurut Ganong (2008:552) “ Hemoglobin adalah pigmen merah pembawa oksigen dalam sel darah merah yang berbentuk bulat dan terdiri atas empat submit".

Hemoglobin sangat penting di dalam latihan, karena Hemoglobin mengangkut oksigen dari paru ke otot yang sedang bekerja. Untuk meningkatkan daya tahan biasanya pelatih memberikan latihan yang didalamnya mengandung beberapa aspek yang berhubungan dengan daya tahan yang terdiri dari latihan Continous Running dan Interval Running. Terdapat banyak latihan yang dapat meningkatkan VO2 Max dan Kadar Hemoglobin. Disini peneliti membantu pelatih untuk menentukan bentuk latihan yang bagus dan tepat untuk diterapkan di dalam sesi latihan untuk menunjang kadar Hemoglobin dan VO2 Max para atlet baseball USBC Universitas Negeri Medan.

VO2 max secara umum menggambarkan kapasitas aerobik seseorang (A. Purba, 2002:121). VO2 max adalah parameter untuk mengukur daya tahan (endurance) menurut Ismanda, dkk (2017:334). VO2 max dapat ditingkatkan dengan cara latihan fisik secara teratur terutama latihan fisik dengan prinsip aerobik yaitu latihan intensitas rendah hinggi intensitas tinggi yang sumber energinya bergantung pada ketersidaan oksigen melalui proses oksigen melalui proses metabolisme aerobik (Putra, 2017:162).

Hemoglobin ialah protein yang kaya akan zat besi. Ia memiliki afinitas (daya gabung) terhadap oksigen dan dengan oksigen itu membentuk oxiHemoglobin di dalam sel darah merah. Dengan melalui fungsi ini maka oksigen di bawa dari paru-paru ke jaringan-jaringan (Pearce, 2006:134). Menurut Putra, dkk (2017:162) Hemoglobin merupakan suatu protein yang mengandung ferit atau zat besi (metaloprotein), yang terdapat di dalam sel darah merah. Suatu molekul Hemoglobin mengandung empat gugus heme (suatu gugus organik yang memiliki sebuah atom ferit atau besi) sehingga mampu mengikat empat molekul oksigen. Sedangkan menurut Aaronson dan Ward (2008:21) Hemoglobin meliki empat submit, masing-masing mengandung rantai polipeptida globin dan porifin yang mengandung besi yang disebut heme. Menurut 
Guyton (2007:535) Hemoglobin tidak hanya mampu mengikat oksigen namun juga mampu mengikat karbondioksida dan karbonmonoksida. Hemoglobin mempunyai peran penting dalam pengangkutan oksigen, karena Hemoglobin mempunyai kemampuan untuk dapat berikatan dengan secara longgar dan reversibel dengan oksigen (Guyton dan Hall, 2007:445). Kandungan normal Hemoglobin rata-rata dalam dalam darah adalah $16 \mathrm{~g} / \mathrm{dL}$ pada pria dan $14 \mathrm{~g} / \mathrm{dL}$ pada wanita (Ganong, 2008:555).

Pemberian program latihan yang tepat untuk meningkatkan tingkat VO2 Max dan kadar hemogolobin atlet sangat diperlukan untuk mencapai prestasi yang diinginkan. Bompa dan Haff (2009) mengemukakan bahwa latihan adalah proses yang dimana seorang atlet mempersiapkan untuk peningkatan level dari kinerja sebelumnya. Menurut Harsono (1988:101) bahwa "latihan (training) adalah proses sistematis dari berlatih atau bekerja, yang dilakukan secara berulang-ulang dengan kian hari menambah jumlah beban latihan atau pekerjaannya". Prinsip beban lebih atau overload adalah prinsip terpenting dalam latihan. Meskipun latihan dilakukan secara terus menerus dan berulang-ulang, dan meski dilaksanakan secara sistematis, akan tetapi apabila tidak dibarengi dengan penambahan beban, maka prestasi tidak akan meningkat.

Ahli-ahli olahraga berpendapat bahwa atlet yang mengikuti suatu program latihan kondisi fisik pre-season yang intensif selama 6-10 minggu akan memiliki kekuatan, daya tahan, dan stamina yang lebih baik selama musim-musim latihan berikutnya, dibandingkan dengan atlet-atlet yang memulai program kondisinya hanya satu-dua minggu sebelum permulaan musim latihan (Harsono, 1988:154).

Sukadiyanto (2005) mengemukakan bahwa Continuous running merupakan aktivitas lari terus menerus dan tidak ada istirahatnya sampai batas waktu. Continuous running dilakukan secara terus menerus tanpa berhenti dan tanpa jeda istirahat. Bentuk aktivitas ini meningkatkan kemampuan menghirup oksigen dan memungkinkan metabolisme berlangsung lebih efesien dan merupakan suatu aktifitas fisik yang berfungsi untuk meningkatkan daya tahan jantung dan paru (kardiorespirasi). Continuous running dapat meningkatkan daya tahan kardiovaskular, dimana dengan adanya pelatihan ini proses penyaluran dan kembalinya darah ke jantung semakin lancar, sehingga mengakibatkan kesempurnaan proses metabolisme dalam tubuh. Nosek (1982:89) mengemukakan bahwa metode Interval didasarkan pada perubahan yang 
direncanakan antara pembebanan dan rekaveri. Interval running merupakan salah satu bentuk variasi dari latihan untuk meningkatkan ketahan aerobik dan aerobik.

Maka dengan adanya program latihan yang memperhatikan prinsip-prinsip tersebut yang diberikan pada bentuk latihan diharapkan akan dapat meningkatkan kadar Hemoglobin $(\mathrm{Hb})$ dan VO2 max atlet sesuai dengan tujuan dalam upaya meningkatkan prestasi atlet.

\section{B. METODE PENELITIAN}

Penelitian ini menggunkan metode eksperimen dengan desain pretest-posttest group design. Dalam penelitian ini terdapat dua kelompok yang dipilih secara total sampling kemudian diberi pretest untuk mengetahui perbedaan keadaan awal antara kedua kelompok eksperimen.

Prosedur penelitian dengan mengambil data awal diperoleh lalu disusun dari nilai yang tertinggi hingga terendah, lalu di matching by fairing untuk membagi menjadi dua kelompok dengan kemampuan yang sama rata. Kelompok 1: diberikan pelakukan yaitu dengan program latihan interval running yang dilakukan selama 6 minggu dengan frekuensi 3 kali dalam seminggu. Kelompok 2: diberikan perlakuan yaitu dengan program latihan continuous running yang dilakukan selama 6 minggu dengan frekuensi 3 kali dalam seminggu, setelah menjalani program latihan maka dilakukan post-test bagi kedua kelompok untuk mengetahui kadar hemoglobin dan VO2 Max pada atlet baseball binaan USBC.

Instrumen penelitian meliputi: Bleep test yang digunakan untuk mengukur kadar VO2 max, CyanmetHemoglobin untuk mengukur kadar hemoglobin, pluit dan stopwatch untuk pelaksanaan program latihan. Populasi dalam penelitian adalah seluruh atlet baseball binaan USBC Universitas Negeri Medan. Sample pada penelitian ini berjumlah 16 orang. Dimana yang 16 orang dibagi menjadi dua kelompok eksperimen yaitu satu sebagai kelompok interval running dan kelompok continuous running. Pemilihan sampel yang dilakukan dengan total sampling.

Data diolah dengan menggunakan program SPSS 20. Dengan uji normalitas dan homogenitas data dengan uji shapiro-wilk. Uji untuk mengetahui perbedaan rata-rata kelompok data yang paired digunakan uji t paired sample statistics. 


\section{HASIL DAN PEMBAHASAN PENELITIAN}

\section{HASIL PENELITIAN}

Data-data yang perlukan untuk analisis data dilakukan memulai test dan pengukuran terhadap 16 orang sampel penelitian, yakni para atlet Baseball binaan USBC Universitas Negeri Medan. Penelitian tersebut dapat dilaksanakan selama 6 minggu dengan frekuensi latihan 3 kali dalam seminggu. Berdasarkan hasil penelitian yang dilakukan, maka dilihat rata-rata kadar hemoglobin dan VO2 Max pre test dan post test pada kelompok interval running dengan hasil sebagai berikut:

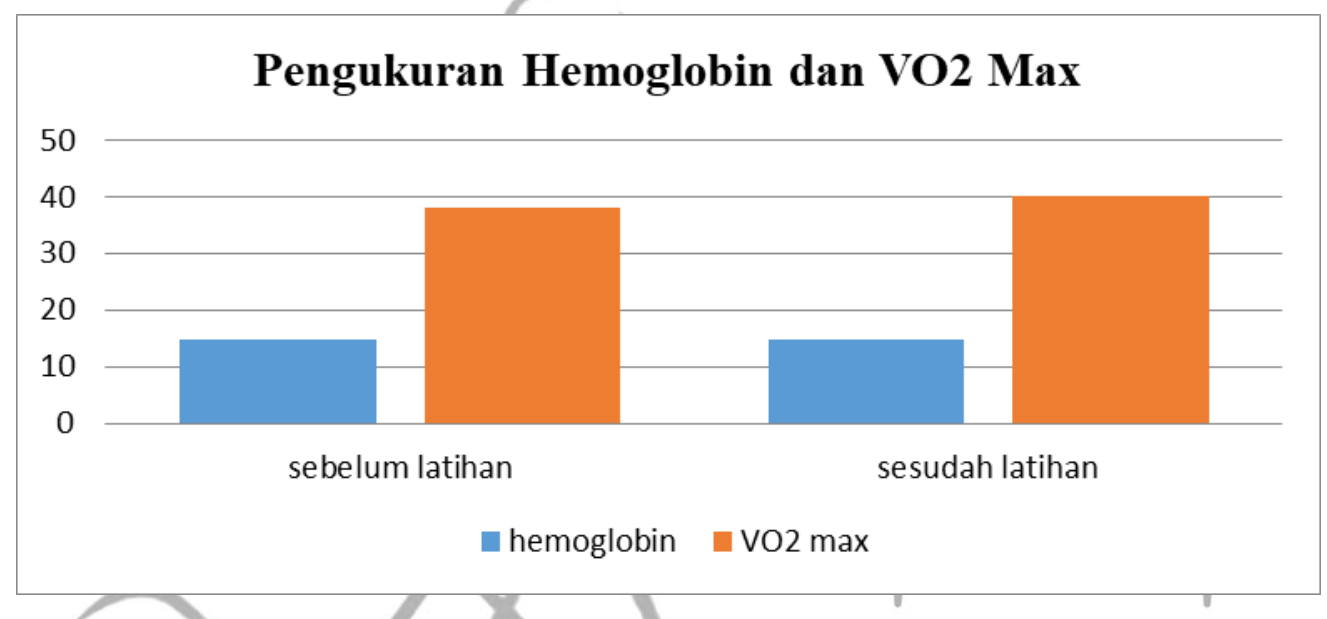

Gambar 1. Pengukuran Hemoglobin Dan VO2 Max Sebelum Dan Sesudah Latihan Interval Running

Berdasarkan hasil penelitian diperoleh kadar hemoglobin pada saat pre test di kelompok interval running menunjukkan rata-rata kadar hemoglobin sebesar 14,85 g/dL dan setelah menjalani program latihan mengalami penurunan sebesar $14,73 \mathrm{~g} / \mathrm{dL}$ dan $\mathrm{p}$ $=0,369$. Terdapat persentase penurunan kadar Hemoglobin setelah latihan Interval Running yaitu 0,81\% dibandingkan sebelum latihan Interval Running. Hasil uji-t menunjukkan ada pengaruh yang tidak bermakna $(\mathrm{p}>0,05)$ dari latihan Interval Running terhadap kadar Hemoglobin seperti pada tabel berikut:

\section{Tabel 1}

Pengaruh Latihan Interval Running Terhadap Kadar Hemoglobin Sebelum Dan Sesudah Perlakuan

\begin{tabular}{|c|c|c|c|}
\hline \multirow{2}{*}{$\begin{array}{c}\text { Kadar Hemoglobin } \\
\text { g/dL }\end{array}$} & \multirow[t]{2}{*}{ Rerata \pm SD } & \multicolumn{2}{|c|}{ Uji-t dependent } \\
\hline & & $\mathbf{T}$ & $\mathbf{P}$ \\
\hline Sebelum latihan & $14,85 \pm 0,86$ & \multirow{3}{*}{0,96} & \multirow{3}{*}{0,369} \\
\hline Setelah latihan & $14,73 \pm 1,03$ & & \\
\hline Beda sebelum dan setelah latihan & 0,12 & & \\
\hline$\%$ penurunan & $0,81 \%$ & & \\
\hline
\end{tabular}


Hasil penelitian lain didapat bahwa rerata VO2 Max setelah latihan Interval Running lebih tinggi dibandingkan sebelum latihan Interval Running yaitu 40,21 $\pm 3,15$ vs $38,03 \pm 2,71, \mathrm{p}=0,000$. Terdapat persentase peningkatan VO2 Max setelah latihan Interval Running yaitu 5,42\% dibandingkan sebelum latihan Interval Running.Hasil uji$t$ dependent menunjukkan ada pengaruh yang bermakna $(\mathrm{p}<0,05)$ dari latihan Interval Running terhadap VO2 Max seperti pada tabel berikut:

Tabel 2

Pengaruh Latihan Interval Running Terhadap VO2 Max Sebelum Dan Sesudah Perlakuan

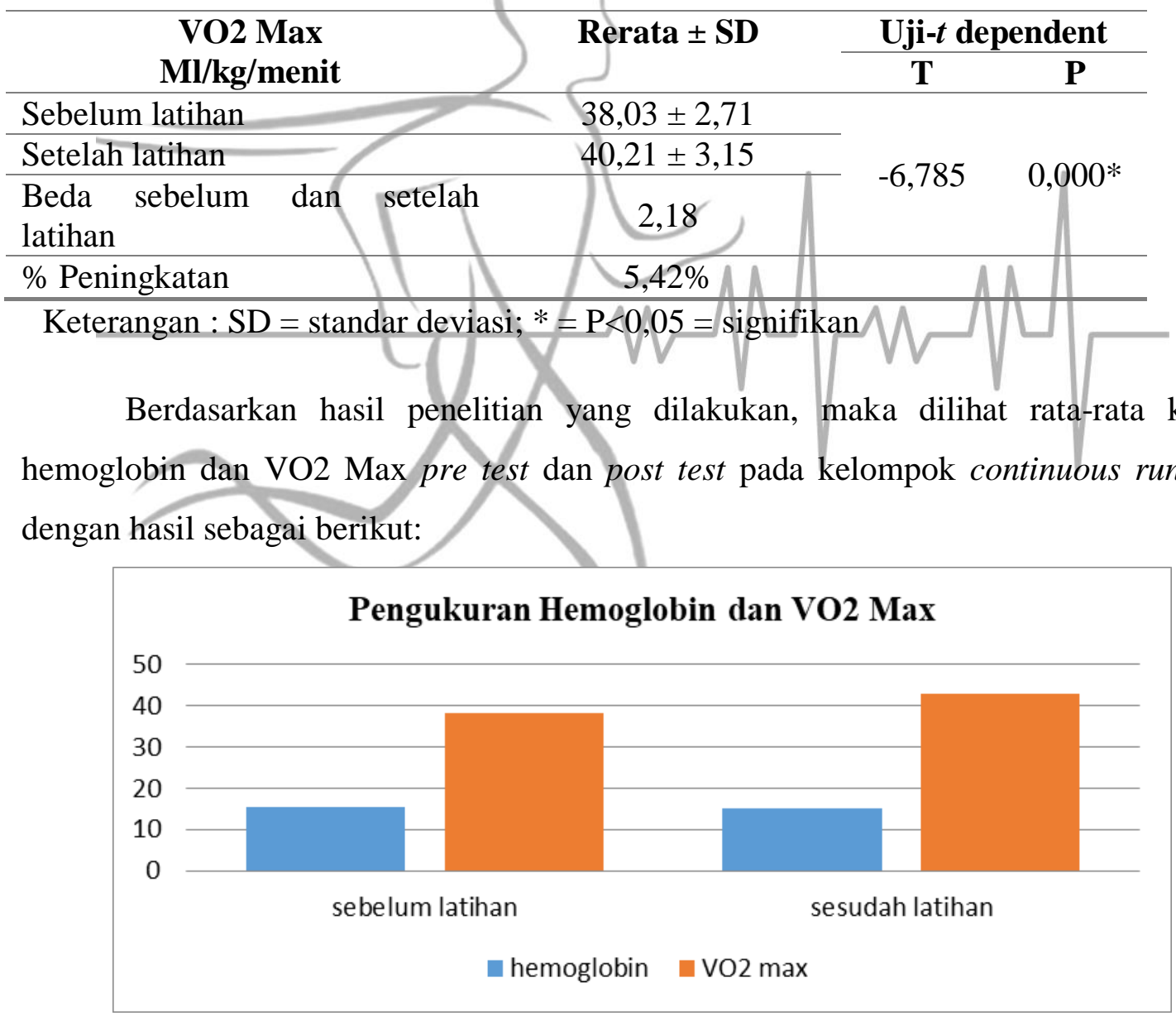

Gambar 2. Pengukuran Hemoglobin Dan VO2 Max Sebelum Dan Sesudah Latihan Continuous Running

Hasil penelitian pada kelompok continuous running menunjukkan rata rata kadar hemoglobin sebesar 15,47 g/dL dan setelah menjalankan program latihan mengalami kenaikan sebesar $15 \mathrm{~g} / \mathrm{dL}$ dan , $\mathrm{p}=0$ 0,089. Terdapat persentase penurunan kadar Hemoglobin setelah latihan Continuous Running yaitu 3,04\% dibandingkan sebelum latihan Continuous Running. Hasil uji-t menunjukkan ada pengaruh yang tidak 
bermakna ( $>00,05)$ dari latihan Continuous Running terhadap kadar Hemoglobin.

Seperti pada tabel berikut:

Tabel 3

Pengaruh Latihan Continuous Running Terhadap Kadar Hemoglobin Sebelum Dan Sesudah Perlakuan

\begin{tabular}{|c|c|c|c|}
\hline \multirow{2}{*}{$\begin{array}{c}\text { Kadar Hemoglobin } \\
\text { g/dL }\end{array}$} & \multirow[t]{2}{*}{ Rerata \pm SD } & \multicolumn{2}{|c|}{ Uji-t dependent } \\
\hline & & $\mathbf{T}$ & $\mathbf{P}$ \\
\hline Sebelum latihan & $15,47 \pm 0,56$ & \multirow{3}{*}{1,970} & \multirow{4}{*}{0,089} \\
\hline Setelah latihan & $15,00 \pm 0,489$ & & \\
\hline $\begin{array}{l}\text { Beda sebelum dan setelah } \\
\text { latihan }\end{array}$ & 0,47 & & \\
\hline$\%$ penurunan & $3.04 \%$ & & \\
\hline
\end{tabular}

Keterangan : $\mathrm{SD}=$ standar deviasi; $*=\mathrm{P}<0,05=$ signifikan

Rerata VO2 Max setelah latihan Continuous Running lebih tinggi dibandingkan sebelum latihan Continuous Running yaitu $42,86 \pm 3,60$ vs $38,075 \pm 2,58, p=0,000$. Terdapat persentase peingkatan VO2 Max/setelah latihan Continuous Running yaitu $11,15 \%$ dibandingkan sebelum latihan Continuous Running. Hasil uji-t dependent menunjukkan ada pengaruh yang bermakna $(\mathrm{p}<0,05)$ dari latihan Continuous Running terhadap VO2 Max sepert pada tabel berikut.

Tabel 4

Pengaruh Latihan Continuous Running Terhadap Kadar VO2 Max Sebelum Dan Sesudah Perlakuan

\begin{tabular}{|c|c|c|c|}
\hline \multirow{2}{*}{$\begin{array}{c}\text { VO2 Max } \\
\text { Ml/kg/menit }\end{array}$} & \multirow[t]{2}{*}{ Rerata \pm SD } & \multicolumn{2}{|c|}{ Uji- $t$ dependent } \\
\hline & & $\mathbf{T}$ & $\mathbf{P}$ \\
\hline Sebelum latihan & $38,07 \pm 2,58$ & \multirow{3}{*}{$-8,910$} & \multirow{3}{*}{$0,000 *$} \\
\hline Setelah latihan & $42,86 \pm 3,60$ & & \\
\hline $\begin{array}{l}\text { Beda sebelum dan setelah } \\
\text { latihan }\end{array}$ & 4,78 & & \\
\hline$\%$ peningkatan & $11,15 \%$ & & \\
\hline
\end{tabular}

Keterangan : $\mathrm{SD}=$ standar deviasi; $*=\mathrm{P}<0,05=$ signifikan.

Untuk mengetahui perbedaan latihan Interval Running dengan latihan Continuous Running terhadap kadar Hemoglobin dan VO2 Max dilakukan uji-t independent. 


\section{Tabel 5}

Perbedaan Rata-Rata Hemoglobin Antara Kelompok Latihan Interval Running Dengan

Kelompok Latihan Continuous Running

\begin{tabular}{|c|c|c|c|}
\hline \multirow{2}{*}{$\begin{array}{c}\text { Kadar Hemoglobin } \\
\text { g/dL }\end{array}$} & \multirow[t]{2}{*}{ Rerata \pm SD } & \multicolumn{2}{|c|}{ Uji-t independent } \\
\hline & & $\mathbf{T}$ & $\mathbf{P}$ \\
\hline Latihan Interval Running & $14,738 \pm 1,03$ & \multirow{4}{*}{$-0,651$} & \multirow{4}{*}{0,526} \\
\hline Latihan Continuous Running & $15,00 \pm 0,489$ & & \\
\hline Beda & 0,622 & & \\
\hline Penurunan \% & $4,15 \%$ & & \\
\hline
\end{tabular}

Keterangan : $\mathrm{SD}=$ standart deviasi $; \mathrm{p}<0,05=$ signifikan

Berdasarkan hasil analisa statistik pada tabel 5 dapat dilihat bahwa rata-rata Hemoglobin setelah menjalankan program latihan Interval Running sebesar 14,738 g/dL dan setelah program latihan Continuous Running sebesar 15,00 g/dL. Hasil uji statistik Uji- $t$ independent diperoleh nilai $\mathrm{p}=0,526$. Hasil ini menunjukkan bahwa tidak terdapat perbedaan yang bermakna $(\mathrm{p}>0,05)$ antara latíhan Interval Running dengan latihan Continuous Running terhadap peningkatan kadâr Hemoglobin pâda atlet baseball binaan USBC Universitas Negeri Medan tahun 2018.

Tabel 6

Perbedaan Rata-Rata VO2 Max Antara Kelompok Latihan Interval Running Dengan Kelompok Latihan Continuous Running

\begin{tabular}{|c|c|c|c|}
\hline \multirow{2}{*}{$\begin{array}{l}\text { VO2 Max } \\
\mathrm{ml} / \mathrm{kg} / \mathrm{menit}\end{array}$} & \multirow[t]{2}{*}{ Rerata \pm SD } & \multicolumn{2}{|c|}{ Uji-t independent } \\
\hline & & $\mathbf{T}$ & $\mathbf{P}$ \\
\hline Latihan Interval Running & $40,21 \pm 3,15$ & \multirow{4}{*}{$-1,564$} & \multirow{4}{*}{0,140} \\
\hline Latihan Continuous Running & $42,86 \pm 3,61$ & & \\
\hline Beda & 2.65 & & \\
\hline Penurunan \% & $6,18 \%$ & & \\
\hline
\end{tabular}

Keterangan : $\mathrm{SD}=$ standart deviasi $; \mathrm{p}<0,05=$ signifikan

\section{PEMBAHASAN PENELITIAN}

Berdasarkan hasil analisa statistik pada tabel 6 dapat dilihat bahwa rata-rata VO2 Max setelah latihan Interval Running sebesar 40,21 $\mathrm{ml} / \mathrm{kg} / \mathrm{menit}$ dan setelah latihan Continuous Running sebesar $42,86 \mathrm{ml} / \mathrm{kg} / \mathrm{menit}$. Hasil uji statistik Uji-t independent diperoleh $\mathrm{p}=0,140$, ini menunjukkan bahwa tidak terdapat perbedaan yang bermakna ( $>0$,05) antara latihan Interval Running dengan latihan Continuous Running terhadap peningkatan VO2 Max pada atlet baseball binaan USBC Universitas Negeri Medan tahun 2018. Hasil uji statistik uji- $t$ independent diperoleh nilai $\mathrm{p}=0,140$, ini menunjukkan bahwa tidak terdapat perbedaaan yang bermakna ( $>0,05)$ antara latihan Interval Running dengan Continuous Running terhadap VO2 Max pada atlet baseball 
binaan USBC Universitas Negeri Medan tahun 2018. Tetapi latihan Continuous Running memiliki rata-rata yang lebih baik dibandingkan latihan Interval Running.

Hal ini kemungkinan dipengaruhi karena tidak adanya kontrol makanan dan minuman serta aktifitas lainnnya selama program latihan berlangsung dikarenakan seluruh subjek di asramakan. Beberapa faktor yang mempengaruhi karena tidak terlalu dikontrolnya kecepatan kelompok Continuous Running disaat menjalankan program latihan yang mungkin saja kecepatan kelompok Continuous Running lebih cepat dari Interval Running. Faktor pelaksaan program juga dapat mempengaruhi hasil penelitian ini.

Pada latihan Interval Running digunakan waktu maksimal yang diambil sebelum dimulainya program latihan untuk mengukur intensitas latihan yang akan dilaksakan setiap sampel untuk menjalankan program setiap minggunya selama 6 minggu, berbeda pada kelompok Continuous Running yang tidak diambil waktu maksimal setiap subjek karena tidak menggunakan intensitas dalam program latihannya.

Penelitian yang dilakukan Hadi (2016) Didapat juga bahwa latihan Continuous Running lebih baik dari pada latihan Interval Running. Menurut Rushall (1992) latihan metode kontinyu adalah latihan yang berlangsung secara secara kontinyu dan sifatnya semakin progresif dari waktu ke waktu. Latihan aerobik merupakan istilah yang digunakan atas dasar system energi predominan yang dipakai dalam aktifitas fisik tertentu. Latihan aerobik ini merangsang kerja jantung, pembuluh darah dan paru. Latihan aerobik biasanya berlangsung lama, sedangkan latihan yang berlangsung cepat biasanya menggunakan system anaerobik. Jika seseorang melakukan latihan selama 6 minggu, maka beban latihan sudah dapat beradaptasi. Lari terus menerus yang lebih dari 30 menit dengan tempo dibawah ambang rangsang anaerobic akan menghasilkan adaptasi aerobic yang baik. Apabila seseorang terus menerus beraktifitas pada system anaerobik, maka ia akan semakin banyak hutang oksigen, dan berakibat semakin banyak asam laktat yang menumpuk dalam tubuh.

Pada penelitian ini didapat Hemoglobin $(\mathrm{Hb})$ peningkatanya menunjukkan perbedaan tidak bermakna $(\mathrm{p}>0,05)$. Melainkan Hemoglobin mengalami penurunan. Data ini sesuai dengan hasil Penelitian yang dilaksanakan Oleh Putra dkk (2017) menunjukkan bahwa pengaruh latihan terhadap kadar Hemoglobin tidak signifikan. Hal ini juga setara dengan penelitian kosasi (2014:180) bahwa tidak terdapat hubungan 
antara aktifitas fisik dengan kadar Hemoglobin. Aktifitas yang berlebihan dapat merusak dinding sel eritrosit dan dapat membuat Hemoglobin $(\mathrm{Hb})$ mengalami penurunan. Hemoglobin sangat bermanfaat dan sangat besar peranannya dalam tubuh manusia dalam melakukan aktifitas (Hairy, 1989:137).

Hemoglobin dapat dipengaruhi oleh asupan makanan yang dimakan seorang atlet. Permasalahan dalam penelitian ini tidak adanya kontrol makanan yang dilakukan peneliti terhadap atlet. Maka penelitian ini diharapkan akan dilanjutkan dan di lakukan lagi dengan lebih spesifik agar mendapatkan hasil yang lebih maksimal dan dapat diketahuinya latihan manakah yang lebih baik dalam peningkatan Hemoglobin.

Keterbatasan penelitian ini karena tidak di asramakannya semua atlet yang menjadi sampel. Sehingga peneliti tidak dapat mengawasi semua aktifitas yang dilakukan atlet selama 6 minggu. Dari makanan atlet, pola tidur atlet, dan kebiasaan kebiasaan yang sering dilakukan atlet selama tidak menjalankan program latihan. Oleh karena itu didapat hasil perbedaan yang tidak signifikan $(\mathrm{P}>0,05)$ dari kedua bentuk latihan yang dilaksanakan.

\section{KESIMPULAN}

1. Tidak terdapat pengaruh yang bermakna latihan Interval Running dan Continuous Running terhadap Hemoglobin, tetapi terdapat pengaruh yang bermakna latihan Interval Running dan Continuous Running terhadap VO2 Max.

2. Tidak terdapat pengaruh yang bermakna antara latihan Interval Running dengan latihan Continuous Running terhadap hemoglobin dan VO2 Max pada atlet baseball binaan USBC UNIMED tahun 2018.

\section{Daftar Pustaka}

Aaronson, Philip I dan Ward, Jeremy P.T. (2008). At a Glance Sistem Kardiovaskular. Edisi Ketiga. Jakarta. Erlangga.

Bompa, Tudor dan Haff, Greg. (2009). Periodization : Theory and Methodology Of Training. Human Kinetics Europe.

Ganong, W.F. (2008). Buku Ajar Fisiologi Kedokteran. Edisi 22. Jakarta. EGC

Guyton dan Hall. (2007). Buku Ajar Fisiologi Kedokteran. Edisi 11. Jakarta. EGC

Hadi, A. (2006). Perbedaan Pengaruh Metode Latihan Continuous Running Dengan Interval Running Dan Kolesterol Terhadap VO2 Max Atlet Sepakbola PPLP Provinsi Aceh. Tesis, Sekolah Pasca Sarjana Universitas Sumatera utara, Medan.

Harsono. (1988). Coaching dan Aspek-Aspek Psikologis Dalam Coaching. Jakarta: Departemen Pendidikan dan Kebudayaan 
Hairy, Junusul. (1989). Fisiologi Olahraga, jilid I. Jakarta: Proyek Pengembangan Lembaga Pendidikan Tenaga Kependidikan.

Ismanda, Shelly Novianti dkk. (2017). Efektifitas Latihan Tahap Persiapan khusus Terhadap Endurance Atlet Pria Junior Cabang Olahraga Taekwondo. Jurnal Terapan Ilmu Keolahragaan Special Issu 01 Seminar Nasional Ilmu Keolahragaan 2017 Hal. 333-338.

Kosasi, Laura dkk. (2014). Hubungan Aktifitas Fisik Terhadap Kadar Hemoglobin Pada Mahasiswa Anggota UKM Pandekar Universitas Andalas. Jurnal Kesehatan Andalas 2014;3(2).

Nossek, Josef. (1982). General Theory Of Training. Surakarta: Terjemahan M. Furqon $\mathrm{H}$.

Pearce, Evelyn C. (2006). Anatomi Dan Fisiologi Untuk Paramedis. Jakarta. PT Gramedia.

Purba, A. (2002). Kardiovaskular Dan Faal Olahraga. Bandung. Bagian Ilmu Faal/ Faal Olahraga Fakultas Kedokteran Universitas Padjadjaran.

Putra, Kukuh Prambuka dkk. (2017). Korelasi Perubahan Nilai VO2 Max, Eritrosit, Hemoglobin dan Hematokrit Setelah Latihan Hgh Intensity Interval Training. Jurnal Keolahragaan, 5(2), 2017, 161-170.

Rushall, B., Pyke, F (1992). Training For Sport and Fitness. The Macmillan Company Of Australia. Pty Ltd.

Sukadiyanto. (2005). Penghantar Teori dan Metodologi: Melatih fisik. Yogyakarta: Universitas Negeri Yogyakarta.

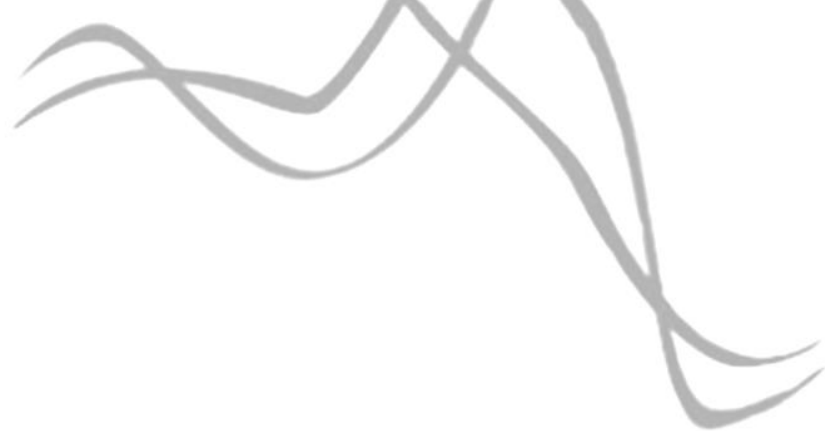

